\title{
An Overview of the Administrative Court and of the Law of Its Establishment in the Republic of Albania
}

Doi:10.5901/ajis.2014.v3n3p177

Arjan Qafa

\section{Abstract}

Administrative Adjudication is the guarantee of effective protection of subjective rights and legitimate interests of the people through a fair trial and within quick and reasonable terms. The establishment of Administrative Court in Albania was a necessity with the sole purpose of creating a more peaceful climate for the progress of the reports between Public Administration and Private Entities. The need for judicial control of the Administrative activity derives from the principle of the the Rule of Law, the latter led by the principle that the subjective rights of citizens should be protected, not only against other people, but also against the Public Administration. This paper addresses the necessity of establishing the Administrative Court and its role in the Republic of Albania, refered to the law for its creation. The activity of the Administrative Court, Administrative Law principles and innovations of this law are analysed here. An important part of this paper is the necessity of creating the Administrative Court referred to the efforts of the EU countries to unify the adoption of a law on Administrative Law. The establishment of this court has also been one of the conditions for the Integration in the European Community. In the context of reforms in the field of Justice and the Legal Administrative Reform in Albania suggested by the European Union conditions have been set for obtaining the Status of an EU candidate country. One of these conditions was also the establishment of the Administrative Court, as the Administrative Justice plays an important role for the economic development of a country.

Keywords: Administrative Court, the Law on the establishment of the Administrative Court, the principles of Administrative Law, Legal Background, Innovations of the Administrative Court.

The establishment of the Administrative Court in Albania was a necessity with the sole purpose of creating a more peaceful climate for the progress of relations between public administration and the private entities.

In the Republic of Albania, judicial power is exercised only by the the Courts, in accordance with the Constitution and the the powers assigned to them by law. Judges have the power to examine all matters determined by law.

The Constitution of the Republic of Albania is prohibited the creation of exceptional courts. This reflected in Article 135, paragraph 2 states: "The Assembly may by law establish the Court for specific fields, but in no case Exceptional Courts". This is reflected in the third paragraph of Article 11 of Law 8436, dated 28.12.1998 "On the Organization of the Judiciary in the Republic of Albania.

In the context of reforms in the field of Justice and the Legal Administrative Reform in Albania suggested by the European Union conditions have been set for obtaining the Status of an EU candidate country. One of these conditions was also the establishment of the Administrative Court, as the Administrative Justice plays an important role for the economic development of a country.

Within these legal provisions and recommendations given by the EU on the positive role played by the Administrative Court, all measures were taken for the establishment of this court.

The Judiciary Function of the Administrative Court focuses on determining the legality of an administrative action, as opposed to the administrative appeal, through which the administrative body examines the legality and regularity of the act.

Administrative courts adjudicate on the legality of a decision of an administrative body, actually by entering the case for finding a solution at the core of the conflict.

Administrative Adjudication is to guarantee effective protection of subjective rights and legitimate interests of the people through a fair trial and within quick and reasonable terms.

Furthermore, the procedure in administrative trials is based on a strict judicial inquiry, without exceeding the principle of the availability of the parties. This is a significant procedural principle, according to which the court which judges the dispute should be expressed on all that is required and only on what is required and the court must be expressed to all requirements set forth in the indictment, skipping its limits.

Judicial review of administrative acts is an essential element of protection system of human rights and at the same time is an indispensable tool for improving the quality of administrative action and consequently to ensure good governance.

Prior to treat judicial control of administrative activity must be treated the meaning of the administrative act, its features and the classification of administrative acts. 
Administrative Act regulates in detail the activities of entities in the relationship they establish between them. In the way the laws regulate, process, sanction and implement the principles of the constitution of a state, the administrative acts are the ones that illustrate the rules of law, pursuant to which they arise. Administrative act is a fundamental concept of administrative justice.

From this point of view, an administrative act must be conceived as a manifestation of a government willingness by the authorities which operate administrative activities, in full compliance with the constitution and the laws, aiming at the establishment, amending, or extinguishing of certain juridical consequences, implemented through free will of the entities to whom it is addressed to or through the restrictive power of the state.

Administrative act is issued for a specific purpose, to establish, amend or extinguish specific juridical consequences for all entities who are obliged to undergo its commandments, and is performed with the desire and the will of the administrative body which has such a right. The will of administrative body is involved in the very nature of the act issued and it is not mentioned explicitly by the law or juridical act in question. The will expressed by the administrative authority in the judicial act aims to achieve a certain goal which is linked to the advent of juridical consequences.

According to the national legislation there are four particulars of the Administrative Act

- Firstly the administrative act is a juridical act; the jurisdictional element of an act defines whether this act establishes or extinguishes a juridical relationship given.

- Secondly the administrative act is unilateral. It is a manifestation of a state juridical will to the competent authority. The unilateral aspect of the act is related to the sense that necessarily and compulsory on its one side lays always the state through the authority of the administration.

- Thirdly the administrative act is the specific for the authorities which perform administrative activities. This feature means that the issuance of an administrative act is the prerogative of the administrative authorities which by law this right is recognized. Administrative authorities having this right are those which (in Article 1) the Administrative Procedure Code recognizes as such.

- Fourthly the administrative act is a bylow (subsidiary act). This feature means that the administrative act must necessarily find support in the law. The task of the administrative body issuing the act is to be based on the law or on the senior act and to implement it.

According to national legislation, the criteria on which the classification of administrative acts is done are as follows

1. Under the initiative for issuing the administrative act, a. Administrative acts issued by the initiative of the authority, b. Administrative acts issued at the request of interested parties, c. Administrative acts issued by the commandments of the law, $\mathrm{d}$. Administrative acts issued by the commandments of court decisions.

2. According to the form and the expression of the will, a. Administrative acts issued in written form, b. Administrative acts issued verbally, c. Administrative acts issued in signs,

3. According to the effect that the act provides, a. Binding administrative acts, b. Constructive and beneficial administrative acts,

4. According to the character of the content of the act, a. Individual administrative acts, b. Normative administrative acts (general)

5. According to the title of the issuing body, a. Decision (Council of Ministers), b. Order (local government bodies), c. Regulation (Minister), d. Instruction (Council of Ministers), e. Normative act with the force of law (Article 101 of the Constitution) f. The order, g. The decree.

The need for judicial control of the Administrative activity derives from the principle of the the Rule of Law, the latter led by the principle that the subjective rights of citizens should be protected, not only against other people, but also against the Public Administration.

The Constitutional Court in its reasoning states that under Article 15 of the Constitution of the Republic of Albania are the fundamental rights and freedoms, those essential elements underlying on the basis of the entire juridical order, consequently, dictate the need for control over the activities of Administration Bodies. It is the Constitution, which in Article 42/2 of guarantees intervention of the judiciary to protect the rights, freedoms and constitutional and legal interests of the individual. Likewise, in the Code of Administrative Procedure (Article 18) it is accepted the principle of judicial control of administrative acts. (Decision No.32, dated 24.11.2003 of The Constitutional Court)

Judicial control of Public Administrative actions by a well functioning Administrative Judiciary, besides strict legal view of individual cases it is also a stimulating force for the modernization of the Public Administration, improving the quality of its services and as a result, increasing citizens' confidence in the effectiveness of the governmental institutions.

However attention should be paid, despite specific law no.49/2012 that entitles the court to issue the act, not all acts can be drawn from the the administrative courts

Pursuant to Article 7 of the Constitution of the Republic of Albania stipulates that the system of governance in 
Albania is based on the separation and balancing between the legislative, executive and judicial government.

The three branches of the government are separate and distinct from each other. This $r$ presupposes independence of governments however it can not be concerned for absolute independence. This independence should be understood as a relative independence in the sense that each authority in its operation should not be affected or subjected by another, but there is no need to overcome the competences among them.

A Public Administrative Court is a specialized type of court in administrative law, particularly for disputes concerning the exercise of the public authority. Their role is to ascertain that official acts are in accordance with the law. Such courts are found in several European countries with civil law and are considered separated from general courts. However a fundamental idea is cast, accepted by all European countries in the last few decades, despite different attitudes regarding the creation and organization of Administrative Jurisdiction. Regardless that the field of the Administrative Trials varies considerably in the legal systems of the different countries, is being established an increasingly stable framework of common principles. Here it is not stated how judicial review should be organized, but there are provided the general rules that must be respected by the Member States in the organization of judicial review of Administrative acts, i.e, it reflects the current state of "European Standards" that must be respected.

In the context of this discussion, the following principles are valid:

Judicial review should be conducted by a court established by law, independent, impartial, which guarantees the Recommendation on Independence conditions.

Efficiency and the Role of Judges.

This basically confirms that the resolution of an Administrative disagreement is an issue of a court established by law, in accordance with the requirements the European Convention on Human Rights. Although the latter were expected to be implemented in the administrative field, the European Court of Human Rights has considered it applicable to administrative cases since 1971.

In some countries, in addition to general courts, there is a separate system of administrative Administrative courts, where general and administrative systems have no jurisdiction over each other, so this development is based on different traditions. Therefore, there exists a local administrative court of first instance, perhaps a Court of Appeal and the Supreme Administrative Court separated from the Supreme Court.

In France, Greece and Sweden, the system has three levels as in the overall system, with the local courts.

As above, the Assembly pursuant to Article 135, paragraph 2 of the Constitution, by law no.49/2012 approved to establish the Special Administrative Courts.

\section{The Administrative Court and Its Role}

The Administrative Court, which aims to ensure the effective protection of subjective rights and legitimate interests of the individuals, through a fair trial and within reasonable and quick terms, increasing the transparency of Administrative decisions, today starts its activity. The opening of this court was one of the conditions required by the European Union for obtaining the status of candidate country, to become part of the great European family.

In the low no.49/2012 it is determined the establishment of the Special Administrative Courts of First Instance, Administrative Court of Appeal and the High Court College, their organization and function as well as the Status of judges that will adjudicate cases on these courts. This law responds best to the concept of the term court specified by law, considered as an element of the regular legal process and as such an integral part of Article 42/1 of the Constitution and Article 6/1 of the ECHR - European Convention on Human Rights (see decision no. 23/2009, and no.16/2012 nr.31/2005 nr.7/2009 and The Constitutional Court).

This law provides the general principles of administrative adjudication and procedural norms relating to the jurisdiction, the competence of the Administrative Courts, the composition of the court under the trial rates and the nature of the cases, as well as procedural stages of the trial until the execution of the decision. So, in general, this law is procedural in nature, but not at the expected level, because no earlier than two months after the entry into force of this law, it was made the adjustment of the legal space by the Supreme Court with the unifying decision with no. 3, dated 06. 12.2013 , concerning the competence of the ordinary courts to review the Administrative cases that were on trial, by shifting these cases to the administrative Court, notwithstanding the trial phase in which these cases were found; decision which addressed the case of the implementation of substantive and procedural law.

In the law no.49/2012 for the establishment of special Administrative Courts of First Instance, the Administrative Court of Appeal and the College in the Supreme Court, for the judgement of Administrative disagreements and the Organization of Administrative Justice, it addresses with priority the principles of Administrative Judgment in general but it devotes importance to: 
1. Effective Protection of the subjective rights of individuals and their legitimate interests.

2. The right to a fair trial and within reasonable terms.

3. Principle of trial in absentia without the presence of the plaintiff, as a result of the failure of the parties to appear in the process. The Administrative Court In the following judges on written acts and the failure of the parties to appear in the process does not constitute a reason to the court recess.

4. The burden of proof, the obligation of the party that truly has the evidences to submitt by imposing sanctions on parties that reject their submission.

Therefore the establishment of these courts brings new innovations under the adjudication of the administrative disputes regarding the obligation of public authorities to present the evidence that enabled the issuance of acts or performance of administrative actions, which afterwards have brought the violation of legal person's rights.

\section{Administrative Courts in Albania and their Organization}

Administrative Courts in Albania are established by Law no.49/2012 as Special Administrative Courts of First Instance in some districts, the Administrative Court of Appeal and the College in the Supreme Court.

Administrative Courts according to the way of the organization are divided into three levels:

1. Administrative Courts of First Instance

2. Administrative Court of Appeal

3. Administrative College in the Supreme Court

- According to this law no.49/2012, the assignment of the Administrative Court of First Instance is done equal in number and territor to that of the Court of Civil Appeals. Relying on these criteria above mentioned, there have been assigned the Administrative Court of Tirana, Durres, Korca, Gjirokastra, Shkodra and Vlora.

- The Administrative Court of Appeal of Tirana which includes under its jurisdiction all Administrative Courts of First Instance.

- Administrative College of the Supreme Court.

The number of Judges in these Courts is determined by the Decree of the President no. 8349, dated 10.14.2013, of the President of the Republic.

Ground Competence, the central headquarters, as well as the number of Administrative Courts of First Instance and of the Administrative Court of Appeals is determined by the decree no. 8349, dated 10.14.2013, of the President of the Republic on the proposal of the Minister of Justice, pursuant to Article 70/5 of Law 49/2012.

- The law no.49/2012 permits the court to develop a part of the activity outside its headquarters (itinerant judge) when it is deemed necessary. Obviously with the rules determined by the Ministry of Justice and the High Council of Justice.

- The judicial panel of the Administrative Court of First Instance consists of three Judges who adjudicate the disputes regarding the public administrative contracts and the requirements outlined in the compliance of letters "d" and "f" of Article 7 of this Law. All other disputes are reviewed with a judicial panel consisting of one Judge.

- The judicial panel of the Administrative Court of Appeal consists of: three Judges, who adjudicate appeals against the decisions of the Administrative Court of First Instance, five Judges, adjudicating the lawsuits against the normative legal act.

- The Supreme Court adjudicates in the Administrative College with a judicial panel consisting of five Judges, except for the cases when otherwise provided by this low.

- The judicial session is held pursuant to the articles of the Civil Procedure Code to the extent they are not inconsistent with this law.

\section{Principles of Law and Administrative Law addressed by the European Administrative Law for its Unification}

European Union countries have attempted to unify the principles of the law of Administrative Law.

\section{Principles of Law and Administrative Law}

The concept of Administrative Law differs from country to country; despite this, attempts were made to agree on a 
common definition of Administrative Law. These efforts are based on a set of principles and rules to be applied to the management and organization of the public administration and the relations between the administration and citizens.

In the field of European Community Law, the European Court has determined a large number of principles of Administrative Law by referring to general legal principles of Administrative Law common to all Member States, in a continuous process. Particularly significant are the principles in the jurisprudence of the European Court, which should be applied by all Member States that should apply those principles themselves: the principle of administration through law, the principle of proportionality, legal certainty, protection of legitimate opportunities, non-discrimination, the right to speak in cases of administrative decision-making procedures, preliminary release, equal conditions for access of individuals in administrative courts, non-contractual liability of Public Administration.

In Western European countries the basic principles of administrative law are identical and are classified as follows:

1) Reliability and predictability (legal certainty);

2) Openness and transparency;

3) Accountability;

4) Efficiency and Effectiveness.

Principles which have been treated as unique to Administrative Law and Administrative Law entirely;

\subsection{Reliability and predictability:}

These relate to legal certainty and juridical security, aiming to eliminate arbitrariness in the conduct of public affairs. The principle of the Rule of Law is a versatile mechanism for reliability and predictability. It assumes the principle of "administration through law". The public administration must decide according to the rule in power as well as according to the interpreting criteria set by the court, without any other consideration. Additional principles also operate in favor of the reliability and predictability such as the principle of procedural fairness, respect for the time, etc.

\subsection{Openness and transparency;}

Openness and transparency are also necessary instruments for the Rule of Law, equality before the law, and accountability. The principle of openness and transparency in public administration serve two specific purposes: on one hand, they protect the public interest as they reduce the opportunity of bad management and corruption; on the other hand, they are essential for the protection of individual rights because they provide the reasons for the administrative decision and therefore help the interested party to exercise the right of redress through Appeals.

\subsection{Accountability;}

Accountability also means that no authority should be exempt from scrutiny. Accountability is an instrument that indicates whether principles of legality, openness, transparency, fairness and equality are respected before the law. Accountability is essential to ensure values such as efficiency, effectiveness, reliability and predictability of Public Administration.

\subsection{Efficiency and Effectiveness;}

Efficiency is a managerial value consisting in essence of maintaining a good ratio between resources and results. Effectiveness consists of ensuring that the performance of Public Administration is successful in achieving the goals and solving public problems set by law and government.

\section{Principles of Law No.49/2012}

Except for principles discussed above about the unification of Administrative Law, the specific law on creating the Administrative Court addresses some principles which are elements of a due process.

\subsection{Speedy trial}

This law creates the possibility of speedy trial within reasonable terms. Administrative Court judgment provides Legal Protection of Rights, Constitutional and legal freedoms and interests of various entities, through a fair trial and within quick and reasonable terms 


\subsection{Burden of proof}

Establishment of this court in Albania brings an innovation within the judgment of the Administrative Disputes, regarding the obligation of public bodies to present the evidence which provided issuance of acts or performance of administrative actions, which then have brought the violation of legal persons' rights.

Public authority has the obligation to prove the legitimacy of administrative acts. Public authority has the obligation to prove the legitimacy of operations in labor relations, from which the dispute has arisen, subject to judgment.

In other cases, the party has the obligation to prove the facts on which bases its claim. But even in these cases, the Court primarily, with an interim decision, may decide shifting the burden of proof to the public body, when there are reasonable suspicions, based on the written evidence, certifying that the public body hides or does not intentionally present facts and evidence relevant to the dispute resolution. This decision is appealed together with the final decision.

- $\quad$ Failure to submit evidence by a public body

Submission of evidence by the parties, in any case, is done before the first court hearing. When does the first deadline designated by the court, the parties shall be given a second term, which must end no later than five days before the hearing. In case of failure to submit the documents within the second designated deadline, the review of the case persists only on acts presented.

Unjustified breach of the obligation to submit the documents by the public body within the second designated deadline is a reason that the court, at the request of the party, imposes a penalty against the head of the public body. The penalty is equal to $20 \%$ of the national minimum wage for each day of delay.

\subsection{Failure to appear does not bring the termination of the trial}

Failure to appear in session does not constitute a due for the cessation of the adjudication of the case, written acts and evidence may be considered by the Court in the consultation room without the presence of the parties, which is not a due for their review.

\subsection{Urgent actions}

This law allows the Administrative Court to carry out some urgent operations without even the presence of the parties, such as defining security measures of the claim, assigning of experts.

These principles of law are treated as new innovations.

Establishment of Administrative Court has caused dispute regarding the jurisdiction of judgment of administrative cases being adjudicated in the ordinary courts.

Concerning this fact ascertained, on disputes between ordinary courts and the specific ones, in conditions when the legislator did not react to give a response to legislative vacuum left on the law no.49/2012, it was a necessity of the Administrative College of the Supreme Court to interfere, in order to pave the way to the stalemate created between the Courts.

Law No.49/2012 does not contain any transitional provisions wherein it is expressed in relation to the law applicable to administrative disputes that were on trial or whose trial had does not yet been completed until 04.11.2013.

Administrative College of the Supreme Court, based on Article 141/2 of the Constitution, and Article 17, paragraph "a" of the law No. 8588, dated 15.03.2000 "On the Organization and Functioning of the Supreme Court of the Republic of Albania", based on the competencies conferred by law has passed the case in the joint colleges to unify the judicial practice.

This unification suggested by the Administrative College of the Supreme Court was to fill this legal vacuum or gap of law no.49/2012, "On the Organization and Functioning of the Supreme Court of the Republic of Albania", unfulfilled by the country's parliament.

The College has assessed that the issue of jurisdiction and a part of the law must be addressed in the United Colleges, with the aim of unifying the judicial practice, an interpretation which serves solving problems that arise in the practice in the courts of all levels as well as the law enforcement in the right way and in accordance with the will of the legislators in the adjudication of administrative cases.

Colleges during the review have addressed in total legal problems of administrative cases filed in civil courts before 04.11.20013, or the examination of which started before that date and has not yet given a final decision on them; another problem paved for handling is that concerning to which procedural law is applicable in this case.

It was laid for discussion The Material Law and the Procedural Law for the Supreme Court 


\section{United Chambers of the Supreme Court consider}

Decree of the President of the Republic no.8349, dated 10.14.2013, has determined the date 11/04/2013, as the day of commencement of operation of Administrative Courts. This date marked the beginning of complete juridical effects and the enforcement in general of the law no.49/2012 regarding the jurisdiction, competence and procedure of adjudication of cases subject to administrative disputes mentioned in Article 7 thereof. Article 72, paragraph 1 and 2, of the law no.49/2012 provides that with the commencement of operation of Administrative Courts, determined by decree of the President of the Republic, are abolished the procedural rates on the substantive and ground competence as well as the special procedural norms, on the dispute Administrative adjudication provided by the Code of Civil Procedure. Joint Colleges of the Supreme Court referred to this situation and legal vacuum, take into consideration the court established by law, in the terms of the court competent to review the administrative disputes. In the following, colleges have addressed the procedural law which must be used during the adjudication of the cases found in the ordinary courts, the new law will be applied.

This attitude, held by the joint colleges comes in comply with the policies of the Constitutional Court, which has consistently stated its view related to the constitutionality of a process, stressing that in the procedural law differently from the material one, the new law is also applicable to the cases on trial, except when otherwise stated by itself, making transitional provisions. (See decision no.106/2002; no.11/2009 of the Constitutional Court.

Referring to this, the fact that the law no.49/2012 is a procedural law containing no transitional provisions to indicate which is the present situation, stage or extent of a trial dispute over which this law extends the effects, then subsequently it is admitted that starting by 04.11 .2013 , this law is applicable to all the cases that itself has defined as administrative dispute, regardless of in what situation, stage or extent the trial is.

Consequently, starting from 04.11.2013 Judicial District Courts Courts of Appeals and the Civil Division of the Supreme Court do not have material jurisdiction to address these administrative cases. As above, the Joint Colleges of the Supreme Court reach a unifying interpretation that: Administrative Courts of First Instance, the Court of Administrative Appeals and the Administrative College of the Supreme Court, established by Law No. 49, dated 03.05.2012 "On the organization and functioning of Administrative Courts and Administrative disputes" are responsible for reviewing all cases which, under Article 7 of this law constitute administrative disputes, despite the state, phase or the extent of the trial. These courts are competent for administrative cases for which the claim, appeal or recourse is filed before 04.11.2013, respectively in the Courts of First Instance, the Court of Appeal or Supreme Court and up to this date, the hearing has not yet finished in these Courts.

The following is addressed as another innovation of this law:

\section{The Expansion of Jurisdiction and the Way to Appeal Against Court Decisions}

In issuing its final decision the court itself may issue an administrative act, may completely or partially rescind Administrative act, may partially or completely change the administrative act or may force the public body to change the Administrative act, (Article 40, Law 49/2012).

\section{New Rules of Jurisdiction}

Not every case can be appealed, the economic criteria is required.

It is not permitted an appeal against the final decision of the Administrative Court for claims with object:

a) Opposing the punishment for committing administrative violations with the value less than 20 times the national minimum wage.

b) Opposing the Administrative Act containing an obligation in cash with the value less than 20 times the national minimum wage.

c) Opposing the Administrative act which has also rejected leaving the due in cash with the value less than 20 times the national minimum wage (appellate and recourse are limited).

\section{Other Innovations Addressed are as Follows}

- The trial at the Administrative Appeal in Counseling Room (Article 49 of the Law).

- Hearing of the Administrative appeal at the Administrative Court of Appeal as a rule is carried on the basis of documents in the consultation room. 
- The court in the consultation room decides the trial hearing in a court session, No.62 of law 49/2012.

Another innovation addressed is as follows:

\section{Execution of Decisions}

Articles 65-66 of this Law refer that: during the compulsory execution proceedings the judge who gave the decision, at the request of the parties or the bailiff, in the consultation room without the presence of the parties orders the performing of special operations and taking other necessary measures by defining the terms and manner of their performing. In case of ascertainment of failure to enforce the decisions, the judge demands disciplinary measures and where appropriate also presents lawsuit against persons.

With the entry into force of the law no.49/2012, and on 04.11.2013, with the operation of Administrative Courts enter into force some amendments to the following laws:

a) Amendment to Law no.8116/2006 Civil Procedure Code of the Republic of Albania.

During the enforcement of the specific law no.49/2012 will be respected all its provisions, which have priority over the previous laws while in other parts where there is no overlap or disputes it will be implemented the Civil Procedure Code of the Republic of Albania.

\section{References}

Constitution of the Republic of Albania

Official Journal of the Republic of Albania

"The Administrative Right ", 1983 (J.Çomo)

The Administrative Right (S.Sadushi)

Law no.49/2012 "On the organization and functioning of Administrative Courts and adjudication of administrative disputes"

Code of Civil Procedure of the Republic of Albania

Code of Administrative Procedure of the Republic of Albania

Decision No.32 dated 24.11.2003 of the Constitutional Court

Unifying decision no. 3 dated 06/12/2013

Decision no.106/2002; no.11/2009 of the Constitutional Court.

Internet, approaches of the well-known authors on administrative area, as well as publications in printed media, etc. 